\title{
Causality between the Construction Sector and GDP Growth in Emerging Countries: The Case of Turkey
}

\author{
By Niyazi Berk* \\ Sabriye Biçen ${ }^{\dagger}$
}

This study empirically investigates the relationship between construction investment and GDP growth in emerging countries. Incentives applied to the construction sector are affecting growth very quickly. However, the construction industry's growth in a sluggish economy is shrinking more than the GDP. Using a Granger causality test for 2000 Q1 to 2016 Q2 period's quarterly data, we examine whether there is a systematic relationship between construction investment and economic growth. In consideration of these findings, the impact on economic growth, as well as economic growth of construction investments in Turkey, should be noted as effective for construction spending.

Keywords: Emerging countries, GDP, Construction, unit root test, causality.

\section{Introduction}

Construction refers to building and infrastructure works in sectors such as energy, defense, and transportation, in both individual and commercial residential areas. The construction sector includes infrastructure such as transportation systems, bridges, dams and irrigation systems, ports, airports, oil pipelines, as well as trendy buildings, such as residential and shopping centers. Project design and management of construction are usually carried out by skilled experts. A separate construction machine and material must be used for each project. Construction is completed with the help of crawler excavators, dozers, and trolleys, graders, lifting platforms and cranes by using basic construction materials consisting of iron, cement, sand, gravel, concrete, plaster, wall covering, wood, paint, plastic, stone, and clay. Construction companies frequently use subcontractors in various jobs like installation, wall, mold, plaster, carpentry, decoration, paint, roof, landscape and so on.

It is generally recognized that the construction industry has a positive impact on national economies by stimulating economic growth. The sector has an important role in the economy in terms of the inputs it uses, due to the demand for goods and services produced by directly or indirectly connected sub-sectors. Considering its connection with other sectors and its contribution to employment, economic growth is accepted as a driving force. As a result of

\footnotetext{
* Professor, Bahcesehir University, Turkey.

${ }^{\dagger}$ Advisor, Biçen Real Estate, Turkey.
} 
these benefits, governments typically designate a significant portion of public spending towards this area.

In addition to machinery, equipment, design and management offices, a large number of unskilled workers are involved in these activities; it is thus the easiest and fastest sector with which to increase employment. Moreover, construction projects, hospitals, cultural centers, libraries, recreation areas, and so on, make an important contribution to socio-economic development of the country. The competitive environment in the construction sector requires that companies operating in this industry can be successful in the medium and long term by focusing on the customer needs and satisfaction. Thus the main determinant of company success is customer satisfaction. For this reason, the quality requirements of the finished product are determined by the customer, both in the construction industry and in the process. This has led to the need to determine the specific demands and expectations for each project by identifying the target group. User satisfaction in the building has an important role among the indicators of the performance of the constructors. In this respect, it is inevitable that customer needs and expectations are reflected in the projects in line with the general tendencies in the construction sector. The results of most academic studies indicate that it is a major source of economic growth and development, particularly for developing countries. The political decision-makers who are aware of this relationship support the sector with various incentives as means of increasing employment. Considering the fundamental importance of the construction sector, it has a significant added value in the national economy due to the effects of capital accumulation, employment, and contribution to the other industries. The purpose of this study is to examine the causal relationship between the construction sector and economic growth specifically in the case of Turkey. It is also intended to suggest new regulations in the areas of sector performance measurement, investment determinants, state support, and competition, wage determination, worker training, and safety. The novelty of this research proposes to make use of the long-term contribution of construction investment (CI) through the existence of a diligent relationship, which will increase the performance of the $\mathrm{CI}$ in the current period and contribute to future economic growth.

\section{Construction in Turkey}

There was a steady growth in total construction output from 1980 to 2001 until Turkey faced an economic crisis. In the following years, the Turkish construction sector maintained its overall growth trend despite some fluctuations. In addition to the major cities of Turkey (i.e., Istanbul, Ankara, and Izmir), there has been a noticeable increase in production in the construction sector and in the sale of real estate to foreign investors in other provinces. However, as a result of deterioration of the main indicators of the Turkish economy, such as rapid depreciation in TL, high unemployment, rising inflation, real decline in export figures, the emergence of high debt problems in dwellings, and the 
reflection of geopolitical developments, the Turkish economy has mainly grown with respect to the construction sector.

The main factors affecting the growth of the construction sector in Turkey in recent years can be listed as follows:

- The planned visa, citizenship, and residence permit facilities for sale of real estate to foreign investors

- The safe harbor position of Turkey, as a result of geopolitical development in the region

- The mortgage financing system that increases housing sales

- The fact that Istanbul is a commercial or geographical distribution center (Hub) and the construction of Istanbul's financial center

- New infrastructure projects that create new interest (Tube passage projects in Istanbul Bosphorus, Third Airport in Istanbul, Osmangazi Bridge, Dardanelles Bridge, and high-speed train projects between Ankara and Istanbul)

- New opportunities for urban transformation

- Movement from the village to the city, as well as refugee migration to the big cities

A new field of work has emerged for the construction sector with urban transformation projects, one of the last examples of change and transformation in Turkey. The old and weak buildings have the opportunity to be transformed into new and modern constructions (EKGYO 2014). Thus, the sector can use its power and experience in structural transformation. Success in the construction and building sector has also grown rapidly outside Turkey, particularly in the neighboring countries. In the past 30 years, Turkish contractors have undertaken about 6,000 projects (about $\$ 200$ billion) in 90 countries.

Government policies, international credit institutions, decisions affecting policy and the economy have a straight impact on the development of the construction sector. It is directly influencing the operation of firms in this area, preferably of the authority that invests or makes the investment decision. In the planning and management of real estate investment, it is necessary to predict the future exactly to be able to lead and to develop new products and markets that will create more value. The construction sector, which directly affects the Turkish economy, must be based on sustainable demographic data for positive and concrete development. The sector, which sheds light on the future, should be examined and regulated on a visionary basis within the framework of these indicators. In Turkey, while the age of marriage has increased in recent years, an increase is seen in divorces. In addition, the number of children has increased rapidly in some social groups while the proportion of single-child and families without children has increased in the other groups. Another point that should be taken into account in the planning of housing is that the fertility is relatively high in the refugees coming to the country.

The construction sector reacted positively to the overall developments in the structure of Turkish economy. Infrastructural investments in the construction 
sector create significant employment in the economy, thus allowing for more investment and development by other sectors of the economy through a multiplier effect.

\section{Literature Review}

Most studies in the construction literature examine the relationship between the construction sector and economic growth for different periods of time. These examinations regarding the causal relationship between construction investments and economic growth reveal different results. In advanced economies, studies on the construction industry are generally exploring the impact of the construction industry on economic growth (Bon \& Pietroforte 1990, Hillebrandt 1985, Lean 2001). A significant number of recent studies have also involved developing countries. Some studies examine the causal relationship between the construction sector and economic growth in developing countries (Kim 2004, Lopes 1998) a small number of studies depict reversed results of economic growth leading to growth in the construction industry (Tse and Ganesan 1997). Construction's data of Hong Kong economy with time series tested longitudinally the relationship between the real growth rate of construction products and the actual growth rate of GDP. GDP growth has led to construction growth and as the GDP growth rate increases, the rate of growth in construction output was marginally diminishing (Yiu et al. 2004).

Some of the studies examining the relationship between construction investments and economic growth reveal that there is a strong relationship, while others express the view that relations may differ in the short and long term. The majority of the research conducted in the construction sector examines the impact on economic growth. Hillebrandt (1985), Bon (1992) and Park (1989) found a positive relationship between the construction sector and total output performance. This contribution of the construction sector to the economy indicates the strong multiplier elements and the importance of forward and backward links between the construction sector and other industries in the national economy. Later studies conducted Ramachandra et al. (2013), and Wong et al. (2008) have not found the same strong relationship between construction sector investments and economic growth. Some other studies conducted on the causality relationship between economic growth and the construction sector for various countries are summarized below.

Construction investment, like housing, infrastructure, etc. in industrialized Western European countries has a direct effect on other investments; however, their effects on the economic growth may be indirect (Turin 1973). In Western Europe, the volume of construction in the GDP in 1980 was $10 \%$, compared to $7 \%$ in 2004 (Wigren and Wilhelmsson 2007). Another study conducted by Bon and Pietroforte (1990) on the UK, Ball \& Wood (1996) on developed countries covers Australia, Canada, Denmark, France, Germany, the Netherlands Japan and the USA in the 1970s and 1980s. This research indicated that the economic role of the construction sector in industrialized Western countries has declined. 
They focus on technology, emphasizing the relative role of manufacturing and service inputs.

The standard industry linking measures have identified the main sources of the induced outputs created by the push and pull effects of the construction industry. Khan (2008) investigates the construction industry with data from Pakistan for the period 1950-2005 to analyze the relationship between construction sector investments and GDP growth rate using the Granger Causality test, which found a strong one-way causality relationship between economic growth and the construction sector. This led to his conclusion that this relationship is moving towards the GDP from the construction sector so that economic growth is largely dependent on investments in the construction sector. Mallick and Mahalik (2008) investigated the role of the construction industry in the Indian economy and its impact on economic growth. They point out that the dominant influence of the capital stock blurred or neutralized the effect of the construction sector. However, they emphasize that the construction industry has increased its economic growth strongly when the capital stock does not add up, thus contributing to the employment of the construction industry. As employment in the construction sector increases, output also increases, which in turn increases the economic growth. However, they underline that these effects do not continue in the long run.

Tiwari (2011) investigated the relationship between construction investment and economic growth for the Indian economy using the data of 1950-1951 and 2008-2009 periods, for a short and long-term, and found that there is a twoway causality relationship between construction investment and economic growth. Thus, this suggests that political decision-makers should encourage investments in the construction sector in the short run, but support should be reduced in the long-term.

Tse and Ganesan (1997) examined the relationship between construction sector investments and economic growth using the data of Hong Kong's economy. In the analysis, the Granger Causality test was used and, unlike the overall outcome of the assessment, it was found that there was a one-way relationship between construction sector investments and economic growth, thus it indicates that investments in the construction sector led to an increase in GDP of the country.

Chang and Nieh (2004) investigated the causal relationship between the construction sector and economic growth in Taiwan. They found that there was cointegration between the construction sector and economic growth. Accordingly, construction activities lead short-to-long economic growth to the one-way relation. As economic growth is determined by external factors, it is stated that this result is consistent with both Neoclassic and Keynesian views. Yiu et al, have investigated the short-term impact of Construction investments on GDP. Using Chinese data the research has indicated that construction investment in short-term has an important impact on the GDP in Hong Kong and US economies. This study also investigated the impact of non-residential investment on GDP. Some Hong Kong and US surveys show surprising results that nonresidential investment has less short-term effects on GDP (Yiu et al. 2002). 
Despite the Similarities, China's Construction and economy grow faster, and their correlation coefficient is higher than which in the US. Therefore, he points out, that it is useful to understand the regulation of construction development for the promotion of construction economy steadily (Hongyu et al. 2002).

Akintoye and Skitmore (1994) examined the relationship between the component of the construction as housing demand, commercial and industrial structures, price level, real interest rate, unemployment and manufacturing profitability, during the period 1974-1988 of the UK private sector construction. The results show that different variables explain the trends in the private sector construction sub-sectors. Commercial and industrial trends are explained by profitability and economic conditions. The level of unemployment affects only the commercial structure and a negative inelastic relationship is identified.

Alagidede and Mensah (2016) conducted a comparative analysis of the relationship between the construction sector and aggregate output for a panel of sub-Saharan African countries using a panel-generalized method of moments. After projecting the effects of institutional structuring, cross-sectional heterogeneity, and non-linearity, the results have confirmed that the construction industry affects growth positively and that the establishment of the right institutions can further improve this effect. The intrinsically non-linear relationship between construction and output growth is much reduced in their sample, suggesting that sub-Saharan African countries have not yet reached the stage of development where construction growth becomes trivial. They also point out that East Africa experienced a strong impact on economic growth from construction, compared to West and Southern Africa. Moreover, the findings of Lopes et al. are consistent with the assumption that the upward trend in the emerging economies tends to follow the general economy model of the construction sector (Lopes et al. 2011).

There are a number of studies that examine the relationship between construction investments and economic growth specifically in Turkey, where economic activities are relatively diversified. Their needs and construction activities are increasing. Çelik (2007) analyzed the economic effects of the construction industry, especially housing construction, in Turkey with the help of a VAR Model and impact-response analysis for the period 1970-2004. As a result of the study, one unit change in the standard deviation of the growth and inflation variables determined that the first two years in the housing variable had a positive effect. For this reason, the increase of housing production in the construction sector indicates that GNP has increased while inflation has fallen, and thus employment has increased over the years. Karg1 (2013) analyzed the causality relationship between economic growth and the construction sector with the Granger test. Using the data of Turkey for the period of 2000 Q01 to 2012 Q03, quarterly reviews show that the growth rate of the construction sector in developing countries is higher than the GDP growth rate in the developed countries, whereas growth rate construction sector is behind the GDP. Furthermore, he determined also that growth rate of the construction sector right after an economic crisis is faster than the GDP growth rate. Bolkol examines the causal relationship between construction sector investments and GDP of Turkey for the period of 2005Q1 to 2013Q4. He found that there is no 
relationship between variables for the long run; however, the causality test indicates that there is a relationship in short run. The findings reveal that the causality runs from GDP to Building Production and Building Production to Non-Building Production. Consequently, he suggests that because there is no relationship between variables in the long run and in the short run, the causality runs from GDP to the construction industry. Thus, a growth strategy mainly based on the construction sector is not reasonable for Turkey (Bolkol 2015).

Kaya et al. (2013) examined the systematic relationship between public and private sector construction investments and economic growth of Turkey in a survey by using the data of 1987-2010. As a result of the conducted Granger causality test, it was determined that this is a one-way relationship from public sector construction investments to GDP and from GDP to public sector construction investments to private sector construction investments. Thus, construction investments in Turkey have an impact on economic growth and economic growth has also affected construction expenditures. Erol and Unal (2015) investigate the causal relationship between construction investments and economic growth of Turkey for the period of 1998 Q1 to 2014 Q4. Using Granger causality tests, they employ a three-variable VAR model (real GDP growth, construction industry growth, and real interest rate) to investigate the causal relationships in a multivariate setting. The paper also employs a further test for determining structural breaks in data. The results indicate that economic growth in Turkey has preceded construction activities with two to four quarter lags, but not vice versa. Finally, they point out that construction activities have short-term effects on economic growth, and thus cannot offer permanent solutions for the economic problems of Turkey. The construction sector responded positively to the developments that took place in political circles and in the overall structure of Turkish economy after these studies. Infrastructural investments in the construction sector create significant employment, thus allowing for more investment and development by other sectors of the economy through the multiplier effect.

\section{Data and Methodology of the Study}

The interrelationships between the construction sector and economic growth on the complex dynamic equilibrium were examined by trends in time series statistical analysis, using construction output of Turkey and share of construction investment in GDP. The data of the study were obtained from the Electronic Data Distribution System (EDDS) of the Central Bank of the Republic of Turkey, TURKSTAT, and Bloomberg. E-Views 8 software is used for the empirical part of the study.

The following variables were used to analyze the relationship between the construction sector and economic growth: GDP (gdp), gross fixed capital formation (gfcf), inflation (cpi), construction expenditure in the GDP (cegdpps), Istanbul Stock Exchange National 100 Index (imkb100), non-metal minerals index (xtast) Istanbul Stock Exchange, and construction expenditure in the GDP Total (cegdptot), 
Before the collected data were analyzed systematically, the relationships between the variables were defined, then the variables were compared and the differences between the variables were determined. Taking into account other analyses from similar studies, we interpreted what the result of each analysis means. The results were combined, and a general assessment of the common result was made. Finally, the estimation results were summarized. In order to increase reliability and facilitate understanding of this study, we have also contacted the construction companies and other experts in the field and reflected the views of firm managers with extensive investments in developing countries to this specific investigation.

\section{Descriptive Statistical Analysis and Findings}

Table 1. Unit Root Tests Results for Variables

\begin{tabular}{|c|c|c|c|c|c|}
\hline & \multicolumn{2}{|c|}{ ADF Unit Root Test } & \multicolumn{2}{|c|}{ PP Unit Root Test } \\
\hline & & Fixed Term & $\begin{array}{c}\text { Fixed Term and } \\
\text { Trend }\end{array}$ & Fixed Term & $\begin{array}{c}\text { Fixed Term } \\
\text { and Trend }\end{array}$ \\
\hline \multicolumn{6}{|l|}{ Level } \\
\hline \multicolumn{2}{|c|}{ DGDP } & -3.074019 & -3.803972 & -8.993904 & -11.45224 \\
\hline \multicolumn{2}{|c|}{ DCTS } & -3.661551 & -3.908299 & -18.44452 & -19.46338 \\
\hline \multicolumn{2}{|c|}{ DCPİ } & -2.515605 & -2.652627 & -7.519070 & -7.464635 \\
\hline \multicolumn{6}{|c|}{ First Differences } \\
\hline \multicolumn{2}{|c|}{$\triangle \mathrm{DGDP}$} & -5.939417 & -5.881466 & -27.06613 & -26.88528 \\
\hline \multicolumn{2}{|c|}{$\Delta \mathrm{DCTS}$} & -5.863061 & -5.804093 & -99.88209 & -100.0711 \\
\hline \multicolumn{2}{|c|}{$\triangle \mathrm{DCPI}$} & -11.08705 & -10.98909 & -28.28202 & -27.03688 \\
\hline \multirow{3}{*}{$\begin{array}{l}\text { Critical } \\
\text { Values }\end{array}$} & $1 \%$ & -3.550396 & -4.127338 & -3.538362 & -4.110440 \\
\hline & $5 \%$ & -2.913549 & -3.490662 & -2.908420 & -3.482763 \\
\hline & $10 \%$ & -2.594521 & -3.173943 & -2.591799 & -3.169372 \\
\hline \multicolumn{6}{|l|}{ Level } \\
\hline \multicolumn{2}{|c|}{ DBIST100 } & -7.532221 & -7.484293 & -7.531512 & -7.482024 \\
\hline \multicolumn{2}{|c|}{ DNME } & -6.707339 & -6.687110 & -6.712269 & -6.689845 \\
\hline \multirow{3}{*}{$\begin{array}{l}\text { Critical } \\
\text { Values }\end{array}$} & $1 \%$ & -2.593090 & -4.118444 & -3.544063 & -4.118444 \\
\hline & $5 \%$ & -2.910860 & -3.486509 & -2.910860 & -3.486509 \\
\hline & $10 \%$ & -2.5930901 & -3.171541 & -2.593090 & -3.171541 \\
\hline \multicolumn{6}{|c|}{ Level } \\
\hline \multicolumn{2}{|c|}{ DGFCF } & 0.1317 & 0.1093 & 0.0000 & 0.0000 \\
\hline \multicolumn{2}{|c|}{ DCPRS } & 0.0017 & 0.0083 & 0.0000 & 0.0000 \\
\hline \multicolumn{2}{|c|}{ DCPUS } & 0.1467 & 0.0000 & 0.0001 & 0.0001 \\
\hline \multicolumn{6}{|c|}{ First Differences } \\
\hline \multicolumn{2}{|c|}{$\triangle \mathrm{DGFCF}$} & 0.0000 & 0.0001 & 0.0001 & 0.0001 \\
\hline \multicolumn{2}{|c|}{$\triangle \mathrm{DCPRS}$} & 0.0000 & 0.0000 & 0.0000 & 0.0000 \\
\hline \multicolumn{2}{|c|}{$\triangle \mathrm{DCPUS}$} & 0.0000 & 0.0000 & 0.0001 & 0.0001 \\
\hline \multirow{3}{*}{$\begin{array}{l}\text { Critical } \\
\text { Values }\end{array}$} & $1 \%$ & -3.550396 & -4.127338 & -3.538362 & -4.110440 \\
\hline & $5 \%$ & -2.913549 & -3.490662 & -2.908420 & -3.482763 \\
\hline & $10 \%$ & -2.594521 & -3.173943 & -2.591799 & -3.169372 \\
\hline
\end{tabular}


The quarterly data for the period 2000 Q1 to 2016 Q2 is being used for empirical analysis. Construction industry flows (DCNS) and Gross Domestic Product (DGDP) data in local currency are employed to analyze the dynamic relationship between GDP and construction sector. All the variables are expressed in different series so that they may be considered with the elasticity of the relevant variables. We examine the contemporaneous correlation and check for the evidence of Granger causality between these two variables. All other test results like Breusch-Godfrey Serial Correlation LM Test, Heteroskedasticity Test: White, Multiple Linear Connections Test and series graphs were added to the appendix.

First, we analyzed unit root tests of all series in the study by using the Dickey-Fuller Test and Phillips Perron Test (Table 1). This table presents the critical and calculated values for the selected indicators at $1 \%, 5 \%$, and $10 \%$ significance levels. DBIST100 and DNME series is stationary at level DGDP, DGTS, and DCPI, while DGFCF, DCPRS, and DCPUS series are stationary after first differencing.

The regression models that were tested are as follows:

Equation 1: $\quad \mathrm{DGDP}=\beta_{0}+\beta_{1} \mathrm{DCTS}+\beta_{2} \mathrm{DCPI}+\varepsilon$

Equation 2: DBIST100 $=\beta_{0}+\beta_{1}$ DNME $+\varepsilon$

Equation 3: $\quad$ DGFCF $=\beta_{0}+\beta_{1}$ DCPRS $+\beta_{2}$ DCPUS $+\varepsilon$

Table 2. Models Equation Estimations

Equation 1: Dependent Variable: DGDP

\begin{tabular}{|c|c|c|c|c|}
\hline Variable & Coefficient & Std. Error & t-Statistic & Prob. \\
\hline DCTS & 2.383527 & 0.625022 & 3.813508 & 0.0003 \\
\hline DCPI & 3596.671 & 742.2926 & -4.845355 & 0.0000 \\
\hline c & 19198.32 & 3299.398 & 5.818733 & 0.0000 \\
\hline R-squared & 0.337212 & \multicolumn{2}{|c|}{ F-statistic } & 15.77210 \\
\hline $\begin{array}{c}\text { Adjusted R- } \\
\text { squared }\end{array}$ & 0.315831 & \multicolumn{2}{|c|}{ Prob (F-statistic) } & 0.000003 \\
\hline
\end{tabular}

Equation 2: Dependent Variable: DBIST100

\begin{tabular}{|c|c|c|c|c|}
\hline Variable & Coefficient & Std. Error & t-Statistic & Prob. \\
\hline DNONMETAL & 0.794591 & 0.076569 & 10.37747 & 0.0000 \\
\hline C & 278.2331 & 464.1278 & 0.599475 & 0.5512 \\
\hline R-squared & 0.646054 & \multicolumn{2}{|c|}{ F-statistic } & 107.6919 \\
\hline $\begin{array}{c}\text { Adjusted R- } \\
\text { squared }\end{array}$ & 0.640055 & \multicolumn{2}{|c|}{ Prob (F-statistic) } & 0.000000 \\
\hline
\end{tabular}

Equation 3: Dependent Variable: DGFCF

\begin{tabular}{|c|c|c|c|c|}
\hline Variable & Coefficient & Std. Error & t-Statistic & Prob. \\
\hline DCPRS & 2.227509 & 0.177389 & 12.55717 & 0.0000 \\
\hline DCPUS & 0.988080 & 0.101566 & 9.728441 & 0.0000 \\
\hline c & 330.5679 & 317.3662 & 1.041598 & 0.3016 \\
\hline R-squared & 0.750333 & \multicolumn{2}{|c|}{ F-statistic } & 93.16519 \\
\hline $\begin{array}{c}\text { Adjusted R- } \\
\text { squared }\end{array}$ & 0.742279 & \multicolumn{2}{|c|}{ Prob(F-statistic) } & 0.000000 \\
\hline
\end{tabular}


Table 2 presents' equations of model estimations and also tells us that there is a relatively weak correlation between construction sector and GDP of Turkey during 2000Q1 to 2016Q2. It is observed that the dependent variable DGDP and the independent variables DCTS and DCPI are significant by examination the model's estimation equation, furthermore, the probe values are $<0.05$ and $\mathrm{R}^{2}$ are 0.33 . Accordingly, only $33 \%$ of the change in a dependent variable can be explained by independent variables. The model's F-statistic and the Prob. value is $<0.05$, indicating that the model is meaningful.

When the second model's estimation equation is examined, it is significant that the dependent variable (DBIST100) and the independent variable (DNME) have probe values $<0.05$. At the same time, the $\mathrm{R}^{2}$ value is 0.64 and thus $64 \%$ of the dependent variable can be explained by independent variables. When we look at the F-statistic and Prob. value of the model, it is $<0.05$, which indicate that the model is meaningful.

When the estimation equation of the third model is examined, the probe values of observed dependent variable DGFCF and the independent variables DCPRS and DCPUS are found less than 0.05. At the same time, the $\mathrm{R}^{2}$ value is 0.75 , which means that $75 \%$ of the change in a dependent variable can be explained by independent variables. Looking at the F-statistic and Prob. value of the model (is $<0.05$ ), which means that the model is meaningful.

\section{Causality Tests}

The causality between variables observed in the following table (Table 3 ). We used Granger Causality Test for data from 2000Q1 to 2016Q2, which includes 63 observations. Constructing the equation as the DGDP dependent variable in the first equation, there is a causality relation between the DCTS independent variable and the dependent variable. But there is no causal relationship between DCPI and DGDP if the dependent variable is DCPI. In other words, there is no causality relation from DCPI to DGDP. When DCTS is accepted as a dependent variable, there is causality relation from independent variable DGDP to the dependent variable. Thus, there is a two-way causality relation between the DCTS and DGDP. However, there is no causal relationship between the DCPI, which is another independent variable, and DCTS, the dependent variable. When DCPI is accepted as a dependent variable, there is a correct causality relation between the DCPI as the dependent variable and the DGDP as the independent variable. The causality relation is also observed from the DCTS independent variable to the DCPI dependent variable (Probe <0.05 Ho: rejected).

The causality relation between the variables was also examined for the second equation and no causality relation was found between BIST 100 index as dependent variable and metal construction index as the independent variable. Their causality is not accepted as $\mathrm{H}_{0}$, with probability value $0.3434>0.05$. At the same time, when the non-metal construction index is dependent and the BIST100 index is taken as an independent variable, the probe value is 0.6907 and this is> 
0.05. This means that there is no causality relationship from an independent variable, to the dependent variable.

Table 3. Granger Causality Test Results

\begin{tabular}{|c|c|c|c|}
\hline \multicolumn{4}{|c|}{ VAR Granger Causality/Block Exogeneity Wald Tests } \\
\hline Sample: 2000Q1 20 & Included ol & & \\
\hline \multicolumn{4}{|c|}{ Equation 1: $\mathrm{DGDP}=\beta_{0}+\beta_{1} \mathrm{DCTS}+\beta_{2} \mathrm{DCPI}+\varepsilon$} \\
\hline \multicolumn{4}{|c|}{ Dependent variable: DGDP } \\
\hline Excluded & Chi-sq & $\mathrm{df}$ & Prob. \\
\hline DCTS & 14.84867 & 2 & 0.0006 \\
\hline DCPI & 3.364969 & 2 & 0.1859 \\
\hline All & 21.96734 & 4 & 0.0002 \\
\hline \multicolumn{4}{|c|}{ Dependent variable: DCTS } \\
\hline Excluded & Chi-sq & $\mathrm{df}$ & Prob. \\
\hline DGDP & 35.40130 & 2 & 0.0000 \\
\hline DCPI & 0.113011 & 2 & 0.9451 \\
\hline All & 52.40942 & 4 & 0.0000 \\
\hline \multicolumn{4}{|c|}{ Dependent variable: DCPI } \\
\hline Excluded & Chi-sq & $\mathrm{df}$ & Prob. \\
\hline DGDP & 12.62360 & 2 & 0.0018 \\
\hline DCTS & 13.63442 & 2 & 0.0011 \\
\hline All & 37.68243 & 4 & 0.0000 \\
\hline \multicolumn{4}{|c|}{ Equation 2: DBIST100 $=\beta_{0}+\beta_{1}$ DNME $+\varepsilon$} \\
\hline \multicolumn{4}{|c|}{ Dependent variable: DBIST100 } \\
\hline Excluded & Chi-sq & $\mathrm{df}$ & Prob. \\
\hline DNONMETAL & 0.792477 & 1 & 0.3734 \\
\hline ALL & 0.792477 & 1 & 0.3734 \\
\hline \multicolumn{4}{|c|}{ Dependent variable: DNONMETAL } \\
\hline Excluded & Chi-sq & $\mathrm{df}$ & Prob. \\
\hline DBIST100 & 0.158284 & 1 & 0.6907 \\
\hline ALL & 0.158284 & 1 & 0.6907 \\
\hline \multicolumn{4}{|c|}{ Equation 3: DGFCF $=\beta_{0}+\beta_{1}$ DCPRS $+\beta_{2}$ DCPUS $+\varepsilon$} \\
\hline \multicolumn{4}{|c|}{ Dependent variable: DGFCF } \\
\hline Excluded & Chi-sq & df & Prob. \\
\hline DCPRS & 9.620497 & 2 & 0.0081 \\
\hline DCPUS & 27.95336 & 2 & 0.0000 \\
\hline All & 66.22600 & 4 & 0.0000 \\
\hline \multicolumn{4}{|c|}{ Dependent variable: DCPRS } \\
\hline Excluded & Chi-sq & df & Prob. \\
\hline DGFCF & 9.353472 & 2 & 0.0093 \\
\hline DCPUS & 23.74081 & 2 & 0.0000 \\
\hline All & 31.90865 & 4 & 0.0000 \\
\hline \multicolumn{4}{|c|}{ Dependent variable: DCPUS } \\
\hline Excluded & Chi-sq & $\mathrm{df}$ & Prob. \\
\hline DGFCF & 28.13981 & 2 & 0.0000 \\
\hline DCPRS & 24.13712 & 2 & 0.0000 \\
\hline All & 103.6495 & 4 & 0.0000 \\
\hline
\end{tabular}


In the third equation, when DCPUS is considered as a dependent variable, causality relation is observed from the independent variables DGFCF and DCPRS to the dependent variable DCPUS. (Probe $<0.05$, Ho: rejected.) According to Granger Causality test results, DGFCF as the dependent variable, there is a oneway causality relationship between the DCPUS independent variable and the dependent variable DGFCF (from DGPUS to DGFCF). However, there is a causality relationship from the independent variable to the dependent variable. In case that DCPRS is accepted as a dependent variable, there is a causality relationship from the DGPUS independent variable. Another independent variable, DGFCF, also has a causality relationship to the dependent variable DCPRS.

\section{Discussion}

In this study, we aimed to examine the causal relationship between construction sector activity and economic growth (GDP). For this purpose, the relationship between the construction sector and the real growth rate of GDP in the paper are analyzed, by using empirical tests of Granger causality with Turkey's quarterly data for the period 2000Q1-2016Q2. Based on the characteristics of Granger causality test, short-term dynamic relationships and long-term equilibrium conditions were investigated.

For this purpose, variables included in the model time of series analysis were first examined with Augmented Dickey-Fuller and Phillips-Perron unit root tests to ensure the stationary of the series and the analyzes were continued based on the results. As the findings in the tables indicate there is no autocorrelation, heteroscedasticity and, as well as, multiple linear connection problems in the model.

Finally, there is a relationship between total construction investments and economic growth in Turkey, which is in parallel with the majority of studies examining the relationship between total construction investments and GDP growth in developing countries. The growth of the Turkish economy is affected by total construction investments; however, it is a weak relationship in the long run.

\section{Conclusions}

During the review period, the relatively low-interest rate provided the real cost of borrowing at low levels. The current account deficit continued to decline, with the contribution of the banking sector's strong and sound structure, there was no significant problem in the loan demand. In 2014, the world was exposed to political and economic risks. In particular, the recession in European economies has also affected the global markets and therefore the Turkish economy. The upward movement of the Dollar and Euro currencies led to an increase in costs in sectoral production, a limited demand for housing, and a slower growth in the construction sector. 
Real estate investments in Turkey are considered safe tools to protect against inflation. Therefore, the positive relationship between construction demand and prices in Turkey is remarkable. Most studies indicate that real estate investment is a protective asset against inflation in the long run. Similarly, there is a positive correlation between construction demand and interest rate inversely, and investors are not considering interest fluctuations in the long run. Finally, there is a positive relationship between per capita national income and construction demand.

In terms of infrastructure provision in the construction sector, job creation, and economic prosperity in most developing countries, the results of surveys conducted in similar countries show significant parallelism. Therefore, political decision makers use the construction sector as an important tool to realize the economic development process. It is also a policy tool to sustain growth and economic equilibrium for the national economy.

Considering the importance of the construction sector, it is possible to solve basic problems in the short run, but new sectors need to be identified to take advantage of the long-term construction investment, as well as increase sector diversification and economic stability. Since the construction industry affects the Turkish economy directly, investment decision in the sector must be based on sustainable demographic data for positive and concrete development. The sector, which sheds light on the future, should be examined and regulated on a visionary basis within the framework of these indicators.

\section{References}

Akintoye A, Skitmore M (1994) Models of UK private sector quarterly construction demands. Construction Management and Economics 12(1): 3-13. DOI = http:// www.tandfonline.com/doi/abs/10.1080/01446199400000002

Alagidede P, Mensah JO (2016) Construction, institutions and economic growth in sub-Saharan Africa Paul Alagidede and Jones Odei Mensah ERSA Working Paper 622 (July 11, 2016).

Ball M, Wood A (1996) Does building investment affect economic growth? Journal of Property Research 13(2): 99-114.

Bolkol HK (2015) Causal Relationship between Construction Production and GDP in Turkey. International Journal of Research in Business and Social Science 4(3). ISSN: 2147-4478.

Bon R (1992) The future of international construction: secular patterns of growth and decline. Habitat International 16(3): 119-128.

Bon R, Pietroforte R (1990) A historical comparison of construction sectors in the United States, Japan, Italy and Finland using input-output tables. Construction Management and Economics 8: 233-247

Çelik S (2007) Türk İnşaat sektörü ve İnşaat Sektörünün Ülke Ekonomisine Etkilerinin Araştırılması [Investigation of the Effects of Turkish Construction Sector and Construction Sector on the Country Economy] (Yayımlanmamış Yüksek Lisans Tezi), İstanbul: Beykent Üniversitesi Sosyal Bilimler Enstitüsü. 
Chang T, Nieh CC ( 2004) A note on testing the causal link between construction activity and economic growth in Taiwan. Journal of Asian Economics 15: 591598.

EKGYO, Emlak Konut GYO A.Ş, (2014). Türk Gayrimenkul sektörü çerçevesinde konut ve konuta bağlı gelişmelerin analizi. Çeyrek Faaliyet Raporu, İstanbul, (ralık 2014). Retrieved from http://bit.ly/2nFjjnu.

Erol I, Unal U (2015) Role of Construction Sector in Economic Growth: New Evidence from Turkey. Retrieved from http://bit.ly/2EYyr3M.

Hillebrandt PM (1985) Economic Theory and the Construction Industry, $2^{\text {nd }}$ ed. London: Macmillan.

Hongyu L, Park YW, Siqi Z (2002)The Interaction between Housing Investment and Economic Growth in China, International Real Estate Review. 5(1): 40-60.

Karg1 B ( 2013) The interaction between the Economic Growth and the Construction Industry: A Time Series Analysis on Turkey (2000-2012). Emerging Markets Journal 3. ISSN 2158-8708.

Kaya V, Yalçınkaya Ö, Hüseyni İ (2013) Ekonomik Büyümede İnşaat Sektörünün Rolü: Türkiye Örneği (1987-2010) [Role of the Construction Industry in Economic Growth: The Case of Turkey (1987-2010)]. Atatürk Üniversitesi İktisadi ve İdari Bilimler Dergisi 27(4).

Khan AR (2008) Role of Construction Sector in Economic Growth: Empirical Evidence from Pakistan Economy, First International Conference on Construction in Developing Countries (ICCIDC-I). Advancing and Integrating Construction Education, Research \& Practice, (August 4-5, 2008), Karachi.

Kim KH (2004) Housing and the Korean Economy. Journal of Housing Economics 13: 321-341.

Lean CS (2001) Empirical tests to discern linkages between construction and other economic sectors in Singapore. Construction Management, and Economics Journal 19(4): 355-363. https://doi.org/10.1080/01446190010022686.

Lopes, J. (1998). The construction industry and macroeconomy in Sub-Saharan Africa post-1970. Construction Management \& Economics, 16(6), 637-649. Published online: 21 Oct 2010. https://doi.org/10.1080/014461998371935.

Lopes J, Nunes A, Balsa C (2011) The long-run relationship between the construction sector and the national economy in Cape Verde, International. Journal of Strategic Property Management 15(1): 48-59. http://dx.doi.org/10.3846/1648715X.2011.5 65909.

Mallick H, Mahalik MK ( 2008) Constructing the Economy: The Role of Construction Sector in India's Growth. J Real Estate Finan Econ 40: 368-384. Retrieved from http://bit.ly/2nFjjnu.

Park SH (1989) Linkages between industry and services and their implications for urban employment generation in developing countries. Journal of Development Economics 30(2): 359-79.

Ramachandra T, Rotimi JOB, Rameezdeen R (2013) The direction of the Causal Relationship between Construction and the National Economy of Sri Lanka. Journal of Construction in Developing Countries 18(2): 49-63.

Tiwari AK (2011) A causal analysis between construction flows and economic growth: evidence from India. Journal of International Business and Economy 12(2): $27-42$.

Tse RTC, Ganesan S (1997) The causal relationship between construction flows and GDP: Evidence from Hong Kong. Construction Management, and Economics 15(4): 371-376. 
Turin DA(1973) The construction industry: Its economic significance and its role in development. Building Economics Research Unit, University College London.

Wigren R, Wilhelmsson M (2007) Construction investments and economic growth in Western Europe. Journal of Policy Modeling 29(3): 439-451.

Wong JMW, Chiang YH, TS Ng (2008) Construction and economic development: The case of Hong Kong. Construction Management and Economics 26(8): 815826.

Yiu CY, Lu XH, Leung MY and Jin WX (2004). A longitudinal analysis on the relationship between construction output and GDP in Hong Kong. Journal of Construction Management and Economics 22(4): 339-345. 
Vol. 4, No. 1

Berk et al.: Causality between the Construction Sector ...

\section{Appendix}

\section{Series Graphs}

DCPI DGDP
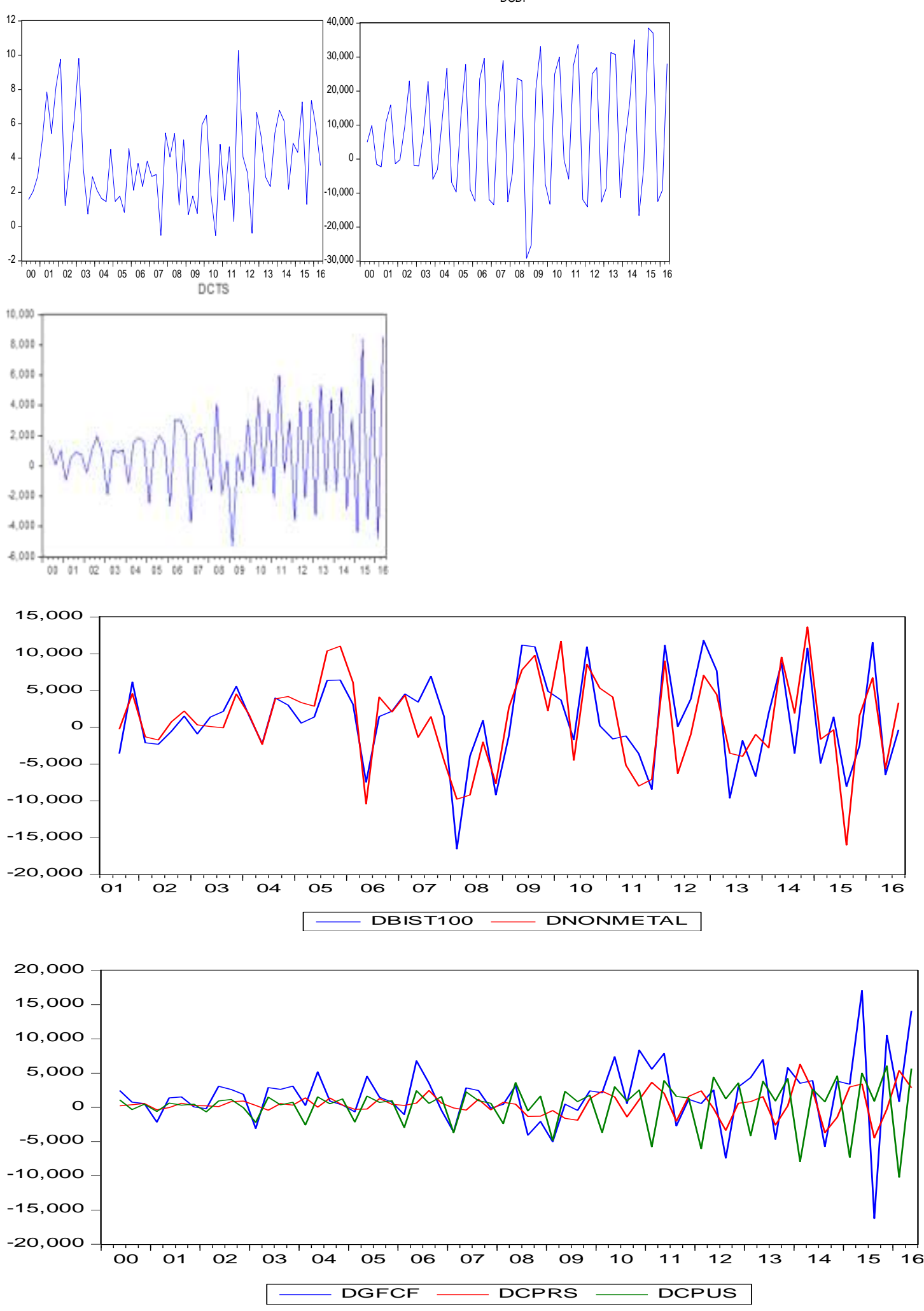


\section{Test Results}

A Breusch-Godfrey Serial Correlation LM (Lagrange multiplier) Test was performed to determine the autocorrelation, and the Ho hypothesis is accepted because the probes $>0.05$ according to the results of this test. prob $=0.97>0.05 ;$ prob $=0.58>0.05 ;$ prob $=0.22>0.05$

Ho: accepted (no autocorrelation problem)

There is no autocorrelation problem in the model.

\begin{tabular}{|c|c|c|c|}
\hline \multicolumn{4}{|c|}{ Equation 1: Breusch-Godfrey Serial Correlation LM Test: } \\
\hline F-statistic & 0.001204 & Prob. F(1,58) & 0.9724 \\
\hline Obs*R -squared & 0.001283 & Prob. Chi-Square(1) & 0.9714 \\
\hline
\end{tabular}

\begin{tabular}{|c|c|c|c|}
\hline \multicolumn{4}{|c|}{ Equation 2: Breusch-Godfrey Serial Correlation LM Test: } \\
\hline F-statistic & 0.300777 & Prob. F(1,58) & 0.5855 \\
\hline Obs*R -squared & 0.314703 & Prob. Chi-Square(1) & 0.5748 \\
\hline
\end{tabular}

\begin{tabular}{|c|c|c|c|}
\hline \multicolumn{4}{|c|}{ Equation 3: } \\
\hline Freusch-Godfrey Serial Correlation LM Test: \\
\hline Obs*R -squared & 1.529594 & Prob. F(1,58) & 0.2209 \\
\hline
\end{tabular}

To determine if there are any variance problems in the model, we conducted the White test and found the value of the probe is $>0.05$ and this result indicate, that the assumption of constant variance is valid.

Prob $=0.0654>0.05 ; \quad$ Prob $=0.4604>0.05 ; \quad$ Prob $=0.1061>0.05$

Ho: accept (no change of variance problem)

There is no heteroscedasticity problem in the model.

\begin{tabular}{|c|c|c|c|}
\hline \multicolumn{4}{|c|}{ Equation 1: Heteroskedasticity Test: White } \\
\hline F-statistic & 4.191196 & Prob. F(5,59) & 0.0025 \\
\hline Obs*R-squared & 17.03611 & Prob. Chi-Square(5) & 0.0044 \\
\hline Scaled explained SS & 10.36913 & Prob. Chi-Square(5) & 0.0654 \\
\hline
\end{tabular}

\begin{tabular}{|c|c|c|c|}
\hline \multicolumn{4}{|c|}{ Equation 2: Heteroskedasticity Test: White } \\
\hline F-statistic & 1.186570 & Prob. F(5,59) & 0.3126 \\
\hline Obs*R-squared & 2.397781 & Prob. Chi-Square(5) & 0.3015 \\
\hline Scaled explained SS & 1.551200 & Prob. Chi-Square(5) & 0.4604 \\
\hline
\end{tabular}

\begin{tabular}{|c|c|c|c|}
\hline \multicolumn{4}{|c|}{ Equation 3: Heteroskedasticity Test: White } \\
\hline F-statistic & 2.537452 & Prob. F(5,59) & 0.0380 \\
\hline Obs*R-squared & 11.50374 & Prob. Chi-Square(5) & 0.0423 \\
\hline Scaled explained SS & 14.49885 & Prob. Chi-Square(5) & 0.1061 \\
\hline
\end{tabular}


The findings also show that there is no problem with multiple linear connections in the model since the centered VIF values are between 1 and 5 .

This model does not have multiple linear connection problems, as the tables indicate.

\begin{tabular}{|c|c|c|c|}
\hline \multicolumn{4}{|c|}{ Equation 1: Multiple Linear Connections } \\
\hline Variable & $\begin{array}{c}\text { Coefficient } \\
\text { Variance }\end{array}$ & $\begin{array}{c}\text { Uncentered } \\
\text { VIF }\end{array}$ & Centered VIF \\
\hline DCTS & 0.390653 & 1.125183 & 1.048239 \\
\hline DCPI & 550998.3 & 3.357853 & 1.048239 \\
\hline C & 10886028 & 3.205692 & NA \\
\hline
\end{tabular}

\begin{tabular}{|c|c|c|c|}
\hline \multicolumn{4}{|c|}{ Equation 2: Multiple Linear Connections } \\
\hline Variable & $\begin{array}{c}\text { Coefficient } \\
\text { Variance }\end{array}$ & $\begin{array}{c}\text { Uncentered } \\
\text { VIF }\end{array}$ & Centered VIF \\
\hline DNONMETAL & 0.005863 & 1.027790 & 1.000000 \\
\hline C & 215414.6 & 1.027790 & NA \\
\hline
\end{tabular}

\begin{tabular}{|c|c|c|c|}
\hline \multicolumn{4}{|c|}{ Equation 3: Multiple Linear Connections } \\
\hline Variable & $\begin{array}{c}\text { Coefficient } \\
\text { Variance }\end{array}$ & $\begin{array}{c}\text { Uncentered } \\
\text { VIF }\end{array}$ & Centered VIF \\
\hline DCPRS & 0.031467 & 1.249141 & 1.169358 \\
\hline DCPUS & 0.010316 & 1.182579 & 1.169358 \\
\hline C & 100721.3 & 1.117724 & NA \\
\hline
\end{tabular}

